\title{
AKTIFITAS ENZIM BROMELIN TERHADAP PENINGKATAN PROTEIN TEPUNG AMPAS KELAPA
}

\author{
Surahman Nur ${ }^{1}$, Surati ${ }^{2}$, Ryan Rehalat ${ }^{3}$ \\ ${ }^{1}$ STKIP-PI Pembangunan, Makassar \\ 2,3 Jurusan Pendidikan Biologi, IAIN Ambon \\ E-mail: surahmannur43@yahoo.co.id
}

\begin{abstract}
Abstrak: Hasil protein terlarut dari ampas kelapa dapat dipengaruhi oleh kerja enzimenzim dari sari nenas, dan juga dipengaruhi oleh kandungan protein dari ampas kelapa itu sendiri. Suatu protein dihidrolisis dengan asam alkali atau enzim akan dihasilkan campuran asam amino dalam bahan-bahan makanan terdapat protein berbeda-beda. Penelitian ini menggunakan merupakan eksperimen laboratorium yaitu mengisolasi bromelin yang terdapat dalam limbah kulit nenas dan menguji pengaruhnya terhadap peningkatan kadar asama amino pada tepung ampas kelapa dalam bentuk Rancangan Acak Lengkap. Hasil penelitian menunjukan bahwa aktifitas enzim bromelin dari ekstrak kulit nenas terhadap peningkatan kadar asam amino tepung ampas kelapa dengan konsentrasi $10 \%, 15 \%, 20 \%, 25 \%$, berpengaruh nyata terhadap peningkatan kadar protein tepung ampas kelapa. Karena penambahan ekstrak kulit nenas pada konsentrasi $25 \%$ memberikan kadar protein terlarut yang tertinggi dan pada konsentrasi $0 \%$ memberikan kadar protein terlarut yang terendah.
\end{abstract}

\section{Kata Kunci: Enzim Bromelin, Kulit Nenas, Ampas Kelapa \\ AN ENZYME BROMELIN ACTIVITY ON INCREASED PROTEIN DREGS COCONUT FLOUR}

\begin{abstract}
: the results of a protein dissolved from the lees coconut can be influenced by the employment enzyme from the juice of the pinaple, and have also been influenced by the moisture content of proteins from the hairs off dregs the cocoanut own. A protein dihidrolisis with an acid to an alkali or to the action of an enzyme will be produced a mixture of of amino acids in ingridiens food there have been instances of different a protein. Was used in the study was an experiment lab where internal conditions pt pgn promised to supply are able to isolate bromelin that was found in any type of waste you the skin pinaple and in testing their influence on elevated levels of asama amino acids in flour dregs coconut in the form of the design of random complete. The results of the study paper work showing that the activity itself to an enzyme bromelin of an extract the skin pinaple to a significant increase in the nature of all that an amino acid flour dregs of
\end{abstract}


coconuts by the concentration of $10 \%, 15 \%, 20 \%, 25 \%$, had have real impact on an increase in levels of a protein flour dregs coconut. Because the addition of an extract the skin nenas at concentrations $25 \%$ give levels of a protein dissolved with the highest overall performance and at concentrations $0 \%$ give levels of a protein dissolved the lowest were reported.

\section{Keywords: An Enzyme Bromelin, The Skin Pinaple, Coconut Dregs}

Nenas merupakan buah-buahan yang mengandung banyak vitamin dan berfungsi sabagai tanaman obat. Mulai dari vitamin A, vitamin C, kalsium, magnesium, natrium, kalium, fosfor, dekstrosa, sukrosa, dan enzim bromelin. Kulit nenas selama ini dianggap kurang berguna dan selalu dibuang bila ingin menikmati buahnya. Limbah kulit nenas tidak bisa dimakan karena terasa gatal di lidah (Anonim, 2011).

Bromelin merupakan salah satu jenis enzim protease sulfhidril yang mempu menghidrolisis ikatan peptida pada protein atau polipeptida menjadi molekul yang lebih kecil, yaitu enzim amino. Bromelin ini berbentuk serbuk amori dengan warna putih bening samapai kekuning-kuningan, berbau khas, larut sebagian dalam: Aseton, Eter, dan $\mathrm{CHCl}_{3}$, stabil pada $\mathrm{pH} 3,0-5,5$. Suhu optimum enzim bromelin adalah $50^{\circ} \mathrm{C}-80^{\circ} \mathrm{C}$. Enzi ini terdapat pada tangkai nenas, kulit, daun, buah, maupun batang nenas yang selama ini kurang di manfaatkan.

Distribusi bromelin pada batang nenas tidak merata dan tergantung pada umur tanaman. Kandungan bromelin pada jaringan yang umumnya belum tua terutama yang bergetah sangat sedikit sekali bahkan kadang-kadang tidak ada sama sekali. Sedangkan bagian tengah batang yang mengandung bromelin lebih banyak dibandingkan dengan bagian tepinya. Berdasarkan hasil penelitian, buah nenas yang masih hijau atau belum matang ternyata mengandung bromelin lebih sedikit dibandingkan buah nenas segar yang sudah matang. Penelitian yang lain menunjukkan buah yang matang karena diperam memiliki kandungan bromelin lebih sedikit dibandingkan buah yang masih hijau.

Berdasarkan kandungan nutriennya, ternyata kulit buah nenas mengandung karbohidrat dan gula yang cukup tinnggi. Kulit nanas mengandung 81, 72\% air, 20, 87\% serat kasar, 17,53\% karbohidrat, 4,41\% protein, dan 13,65\% gula reduksi. Mengingat kandungan karbohidrat dan gula yang cukup tinggi tersebut, maka kulit nanas memungkinkan untuk dimanfaatkan sebagai bahan baku pembuatan bahan kimia, salah satunya Etanol melalui proses pembuatan tepung dari ampas kelapa.

Buah kelapa (Cocos nucifera L.) selain sebagai sumber karbohidrat juga sebagai sumber lemak, protein, kalori, vitamin, dan mineral. Nutrisi karbohidrat yang terkandung dalam daging kelapa sebesar 10-14 g/100g berat basah. Buah kelapa juga mengandung serat kasar 30,58\%. Analisis ampas kelapa kering mengandung 13\% selulosa dapat berperan dalam proses fisiologi tubuh. Ampas kelapa didapatkan dari parutan daging 
kelapa ditambah air diperas hingga keluar santannya. Ampas kelapa merupakan hasil samping pembuatan menjadi minyak kelapa dari pengolahan cara basa akan diperoleh hasil samping ampas kelapa (Meddiati. F, 2010).

Pemamfaatan tepung ampas kelapa dalam pemgembangan produk pangan, merupakan mensubstitusi tepung terigu. Pengolahan tepung ampas kelapa berserat kasar tinggi, sebagai bahan baku makanan rendah kalori hanya mengikuti pemanfaatan kelapa untuk pengolahan santan dan minyak cara basah, sebab yang digunakan adalah hasil sampingan ampas kelapa. Meskipun ampas kelapa merupakan hasil sampingan pembuatan santan, namun karena kandungan seratnya cukup tinggi maka ampas kelapa dapat dimanfaatkan sebagai bahan substitusi pada produk pangan. Olehnya itu tepung dari ampas kelapa sangat baik digunakan sebagai salah satu bahan dalam membuat formula makanan, khusus untuk konsumen yang beresiko tinggi terhadap penyakit obesitas, kardiovaskuler dan lain-lain.

Tepung merupakan hasil olah yang dibuat dengan cara pemanasan dan pengurangan kadar air yang kemudian bahan kadar airnya cukup rendah $( \pm 10 \%)$ ditumbuk halus dan dilakukan pengayakan agar seragam. Tepung ampas kelapa dapat digunakan sebagai bahan substitusi berbagai produk pangan, diantaranya cookies (kue kering), nugget, lumpia, roti, brownies dan lain-lain (Syarif dan Aris, 1986). Protein diperlukan untuk pertumbuhan dan perkembangan tubuh, pergantian dan perbaikan selsel jaringan tubuh yang rusak dan produksi enzim pencernaan dan enzim metabolism (Anonim, 2011). Setiap sel mengandung protein. Protein senyawa organik esensial bagi makhluk hidup dan konsentrasinya paling tinggi di dalam jaringan otot hewan. Protein merupakan bahan esensial yang menunjang kehidupan kulit, tulang otot, otot, darah, hormon, enzim dan organ-organ dalam semuanya tersusun dari protein.

Protein adalah senyawa organi yang terdiri dari satu atau lebih asam amino. Asam amino didapatkan dari sumber-sumber protein. Protein yang didapatkan melalui makanan sehari-hari diurai dalam percernaan dalam bentuk asam amino (Anonim, 2011). Kadar asam amino pada tepung ampas kelapa dapat ditingkatkan, diantaranya dengan melihat aktifitas ekstrak kulit nenas pada ampas kelapa yang dibuat dalam bentuk tepung.

\section{METODE PENELITIAN}

Penelitian ini merupakan eksperimen laboratorium yaitu mengisolasi bromelin yang terdapat dalam limbah kulit nenas dan menguji pengaruhnya terhadap peningkatan kadar asama amino pada tepung ampas kelapa. Penelitian ini terdiri dari dua variabel yaitu: konsentrasi ekstrak kulit nenas (bromelin) sebagai variabel bebas, dan kadar asam amino tepung ampas kelapa sebagai variabel terikat.

Percobaan ini dilakukan dengan menggunakan Rancangan Acak Lengkap (RAL) satu faktor, dengan rumus statistiknya yaitu uji Anova dan penyusunannya sebagai berikut: 
P0 : Tepung ampas kelapa $50 \mathrm{~g}$ tanpa ditambah ekstrak kulit nenas + Aguadest $100 \mathrm{ml}$

P1 : Tepung ampas kelapa $50 \mathrm{~g}+$ ekstrak kulit nenas $10 \mathrm{ml}+$ Aquades $90 \mathrm{ml}$

P2 : Tepung ampas kelapa $50 \mathrm{~g}+$ ekstrak kulit nenas $15 \mathrm{ml}+$ Aquades $85 \mathrm{ml}$

P3 : Tepung ampas kelapa $50 \mathrm{~g}+$ ekstrak kulit nenas $20 \mathrm{ml}+$ Aquades $80 \mathrm{ml}$

P4 : Tepung ampas kelapa $50 \mathrm{~g}+$ ekstrak kulit nenas $25 \mathrm{ml}+$ Aquades $75 \mathrm{ml}$

Prosedur penelitian/prosedur kerja adalah:

\section{Sterilisasi alat}

Semua alat yang digunakan pada penelitian ini dibersihkan terlebih dahulu, kemudian dikeringkan dengan menggunakan oven pada suhu $50-60{ }^{0} \mathrm{C}$ selama 2 jam.

\section{Cara kerja}

a. Pembuatan Ekstrak Kulit Nenas

1) Ekstrak kulit nenas diperoleh dengan cara menimbang 1000 gram kulit nenas

2) Kulit nenas dicuci dengan air mengalir sampai bersih

3) Kemudian kulit nenas diblender sampai hancur.

4) Kulit nenas yang telah halus lalu disaring menggunakan penyaring yang berukuran 100 Mesr sehingga diperoleh ekstrak kulit nenas kasar.

5) Membuat perlakuan pada ekstrak yang diperoleh, dan selanjutnya diujikan pada tepung ampas kelapa.

b. Pembuatan Tepung Ampas Kelapa

1) Kelapa dikupas kemudian diparut.

2) Setelah itu tambahkan air, kemudian diremas, diambil ampasnya, santannya dibuang

3) Ampas kelapa dikeringkan di bawah terik matahari selama 3 atau 4 hari.

4) Setelah kering, ampas kelapa di tumbuk sampai halus

5) Kemudian ditimbang sesuai perlakuan.

c. Penentuan Kadar Asam Amino

1) Tepung ampas kelapa direndam pada ekstrak kulit nenas berdasarkan perlakuan kemudian dishaker selama 24 jam berguna untuk menghomogenkan perlakuan.

2) Lalu dicentrifugasi selama 10 menit dengan kecepatan $1200 \mathrm{rpm}$ untuk memisahkan dengan endapan.

3) Kemudian saring dengan menggunakan penyaringan dan ambil ampasnya.

4) Setelah itu dikeringkan di oven sampai benar-benar kering dengan suhu $40{ }^{\circ} \mathrm{C}$.

5) Selanjutnya diperiksa kadar proteinnya.

\section{d. Pembuatan Pereaksi Biuret}

1) Menyediakan $\mathrm{NaOH} 40 \%$ dan $\mathrm{CuS} 045 \mathrm{H} 2 \mathrm{O} 1 \%$

2) Mengambil $\mathrm{NaOH} 40 \% 100 \mathrm{~mL}$ dan $\mathrm{CuS} 045 \mathrm{H} 2 \mathrm{O}$ sebanyak $20 \mathrm{ml}$ kemudian dilarutkan atau dicampurkan sehingga terbentuklah biuret.

Data diperoleh dari hasil pengukuran kadar asam amino tepung ampas kelapa yang telah peram dengan ekstrak kulit nenas sesuai dengan perlakuan, dengan 
menggunakan spektrofotometri pada panjang gelombang $280 \mathrm{~nm}$. Data yang terkumpul dari hasil pengukuran dianalisis dengan menggunakan uji analisis varian satu jalur (ANAVA) pada taraf signifikan 5\%, jika ada pengaruh maka dilanjutkan dengan uji BNT.

\section{HASIL DAN PEMBAHASAN}

Penelitian ini digunakan untuk uji aktifitas enzim bromelin dari ekstrak kulit nenas (Ananas comosus Merr L.) terhadap peningkatan kadar asam amino tepung ampas kelapa (Cocos nucifera L.), dengan 5 perlakuan dan 3 kali ulangan. Sehingga hasil penelitian tersebut adalah sebagai berikut:

Tabel 1. Uji Aktifitas Enzim Bromelin Terhadap Peningkatan Kadar Asam Amino

\begin{tabular}{|c|c|c|c|c|c|}
\hline \multirow[b]{2}{*}{ Perlakuan } & \multicolumn{3}{|c|}{ Ulangan } & \multirow{2}{*}{$\begin{array}{l}\text { Total } \\
\text { Perlakuan } \\
\text { (Y.i) }\end{array}$} & \multirow{2}{*}{$\begin{array}{l}\text { Rata - Rata } \\
\text { (Y) }\end{array}$} \\
\hline & 1 & 2 & 3 & & \\
\hline P0 & 5,26 & 5,02 & 5,33 & 15,61 & 5,20 \\
\hline $\mathrm{P} 1$ & 5,63 & 5,68 & 5,71 & 17,02 & 5,67 \\
\hline $\mathrm{P} 2$ & 6,13 & 6,19 & 6,21 & 18,53 & 6,18 \\
\hline P3 & 6,89 & 6,72 & 6,81 & 20,42 & 6,81 \\
\hline $\mathrm{P} 4$ & 7,14 & 7,19 & 7,22 & 21,55 & 7,18 \\
\hline Total Y.j & 31,05 & 30,8 & 31,28 & 93,13 & 31,04 \\
\hline
\end{tabular}

(Data Primer: Agustus 2014)

Tabel 1 menunjukkan adanya sedikit perbedaan antara kadar protein pada perlakuan P1, P2, dan P4. Hasil analisis sidik ragam dengan tabel varians (ANAVA) analisis enzim bromelin dari ekstrak kulit nenas terhadap peningkatan kadar asam amino tepung ampas kelapa memperlihatkan pengaruh yang nyata, untuk lebih jelasnya dapat dilihat pada tabel 2 di bawah ini:

Tabel 2. Analisis Varians (ANAVA)

\begin{tabular}{|l|l|l|l|l|l|}
\hline $\begin{array}{l}\text { Sumber Keragaman } \\
(\mathrm{SK})\end{array}$ & $\begin{array}{l}\text { Derajat Bebas } \\
(\mathrm{DB})\end{array}$ & $\begin{array}{l}\text { Jumlah Kuadrat } \\
(\mathrm{JK})\end{array}$ & $\begin{array}{l}\text { Kuadrat Tengah } \\
(\mathrm{KT})\end{array}$ & F Hitung & F Tabel \\
\hline Perlakuan & 4 & 7,82 & 1,95 & 288,05 & 4,96 \\
\hline Galat & 6 & 0,054 & 0.0067 & & \\
\hline Total & 10 & 7,875 & & & \\
\hline
\end{tabular}

Sumber: hasil Penelitian, September 2015.

Tabel 2 menunjukan bahwa sumber variasi untuk perlakuan diperoleh derajat kebebasan $=4$, jumlah kuadrat perlakuan $=7,82$, kuadrat tengah perlakuan $=1,95, \mathrm{~F}$ hitung $=288,05, \mathrm{~F}$ tabel $=4,96$ sedangkan sumber variasi untuk enzim bromelin dari ekstrak kulit nenas terhadap peningkatan kadar asam amino tepung ampas kelapa diperoleh derajat bebas galat $=6$ jumlah kuadrat galat $=0,054$, kuadrat tengah galat $=$ 0,00675, sehingga dari hasil uji beda nyata terkecil (BNT) dapat dimasukan dalam tabel berikut: 
Tabel 3. BNT

\begin{tabular}{|l|l|l|}
\hline No & Perlakuan & Rata-Rata \\
\hline 1 & $\begin{array}{c}\text { P0 : Tepung ampas kelapa 50 g tanpa ditambah ekstrak kulit nenas + } \\
\text { Aguadest } 100 \mathrm{ml} \text { (kontrol) }\end{array}$ & $5,20^{\mathrm{a}}$ \\
\hline 2 & $\begin{array}{c}\text { P1 : Tepung ampas kelapa } 50 \mathrm{~g}+\text { ekstrak kulit nenas } 10 \mathrm{ml}+\text { Aquades } \\
90 \mathrm{ml}\end{array}$ & $5,67^{\mathrm{ab}}$ \\
\hline 3 & $\begin{array}{c}\text { P2: Tepung ampas kelapa } 50 \mathrm{~g}+\text { ekstrak kulit nenas } 15 \mathrm{ml}+\text { Aquades } \\
85 \mathrm{ml}\end{array}$ & $6,18^{\mathrm{c}}$ \\
\hline 4 & $\begin{array}{c}\text { P3: Tepung ampas kelapa } 50 \mathrm{~g}+\text { ekstrak kulit nenas } 20 \mathrm{ml}+\text { Aquades } \\
80 \mathrm{ml}\end{array}$ & $6,81^{\mathrm{cd}}$ \\
\hline 5 & $\begin{array}{c}\text { P4: Tepung ampas kelapa } 50 \mathrm{~g}+\text { ekstrak kulit nenas } 25 \mathrm{ml}+\text { Aquades } \\
75 \mathrm{ml}\end{array}$ & $7,18^{\mathrm{e}}$ \\
\hline BNT 5\% & $\mathbf{4 , 0 2 1 4}$ \\
\hline
\end{tabular}

Keterangan: Angka yang diikuti oleh huruf yang sama, tidak berbeda nyata pada taraf uji BNT 0,05.

Dari tabel tersebut, maka jumlah nilai kritis BNT 5\% $=288,05$ dengan nilai ratarata aktifitas enzim bromelin dari ekstrak kulit nenas (Ananas comosus Merr L.) terhadap peningkatan kadar asam amino tepung ampas kelapa (Cocos nucifera L.) terberat $(7,18)$ terdapat pada perlakuan $\left(\mathrm{P}_{4}\right)$ yaitu Tepung ampas kelapa $50 \mathrm{~g}+$ ekstrak kulit nenas $25 \mathrm{ml}$ + Aquades $75 \mathrm{ml}$, dan berbeda nyata dengan perlakuan $\left(\mathrm{P}_{3}\right.$ dan $\left.\mathrm{P}_{2}\right)$ yaitu $(6,81$ dan 6,18$)$, dan terendah terdapat pada perlakuan $\left(\mathrm{P}_{0}\right)$ yaitu tanpa perlakuan (kontrol) yaitu $(5,20)$, untuk lebih jelas dapat dilihat pada Grafik berikut:

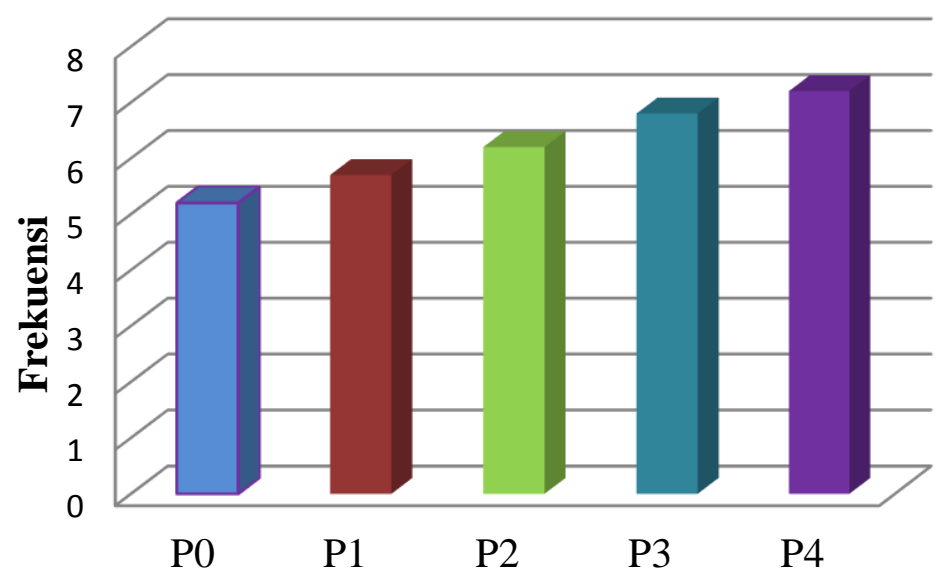

Gambar 1. Hubungan Konsetrasi Bromelin dengan Kadar Protein

Sehingga dengan melihat koefisien keragaman yaitu 2,728, dengan hasil pengujian hipotesis penelitian, maka dapat bahwa $\mathrm{H}_{\mathrm{i}}$ diteima dan $\mathrm{H}_{0}$ ditolak, dengan analisis hasil sebagai berikut: $\mathrm{F}_{\text {hitung }}>\mathrm{F}_{\text {tabel. }}$. Ada pengaruh aktifitas enzim bromelin dari ekstrak kulit nenas (Ananas comosus Merr L.) terhadap kadar asam amino tepung ampas kelapa (Cocos nucifera L.). 
Hasil uji anava diperoleh nilai $F_{\text {hitung }}>F_{\text {tabel }}$ yaitu 288,05 $<4,96$ pada taraf signifikan 5\%, artinya penambahan ekstrak kulit buah nenas berpengaruh nyata terhadap peningkatan kadar protein pada tepung ampas kelapa, dan secara deskriptif memperlihatkan adanya perbedaan kadar protein tepung ampas kelapa pada konsentrasi ekstrak kulit nenas yang berbeda-beda, dimana tingginya volume ekstrak kulit nenas yang ditambahkan yang berarti semakin tinggi pula konsentrasi enzim bromelin. Pada umumnya asam amino diperoleh sebagai hasil hidrolisis protein, baik menggunakan enzim maupun asam. Protein yang didapatkan melalui makanan sehari-hari diurai dalam percernaan dalam bentuk asam amino. Fungsi asam amino antara lain adalah penyusun protein: termasuk enzim, kerangka dasar sejumlah senyawa penting dalam metabolisme (terutama vitamin, hormon, dan asam nukleat), dan penggikat logam penting yang diperlukan dalam reaksi enzimatik.

Hal ini menyebabkan kadar protein tepung ampas kelapa dengan penambahan ekstrak kulit buah nenas lebih tinggi dari pada kadar protein pada tepung ampas kelapa tanpa penambahan ekstrak kulit buah nenas, karena bromelin berfungsi untuk mengkatalis protein dalam tepung ampas kelapa. Peningkatan kadar protein pada tepung ampas kelapa yang ditambahkan ekstrak kulit buah nenas disebabkan oleh kandungan bromelin pada nenas. Enzim bromelin merupakan suatu enzim protease yang mampu memecah protein. Enzim ini mempunyai arti penting seperti halnya papain yang dihasilkan dari tanaman pepaya. Proses kerja enzim bromelin adalah memecah protein menjadi asam amino.

Bromelin dapat diperoleh dari tanaman nenas baik dari tangkai, kulit, daun, buah, maupun batang dalam jumlah yang berbeda. Dilaporkan bahwa kandungan enzim bromelin lebih banyak terdapat pada batang yang selama ini kurang dimanfaatkan. Distribusi bromelin pada batang nenas tidak merata dan tergantung pada umur tanaman. Kandungan bromelin pada jaringan yang umurnya belum tua terutama yang bergetah sangat sedikit sekali bahkan kadang-kadang tidak ada sama sekali. Sedangkan bagian tegah batang mengandung bromelin lebih banyak dibandingkan dengan bagian tepinya.

Asam amino merupakan unit pembangun protein yang dihubungkan melalui ikatan peptida pada setiap ujungnya. Pada umumnya, asam amino larut dalam air dan tidak larut dalam pelarut organik nonpolar seperti eter, aseton, dan kloroform. Tidak semua asam amino yeng terdapat dalam molekul protein dapat dibuat dalam tubuh kita. Hasil uji pada penelitian ini menunjukkan bahwa P4 (perlakuan dengan penambahan ekstrak kulit buah nanas 25\%) merupakan perlakuan yang memiliki kadar protein paling baik dari perlakuan lainnya. Kadar protein tepung ampas kelapa yang ditambahkan ekstrak kulit buah nenas sebanyak 25\% (P4) sebesar 21,55 ppm, pada penambahan ekstrak kulit buah nenas 20\% (P3) sebesar 20,42 ppm, pada penambahan ekstrak kulit buah nenas $15 \%$ (P2) sebesar 18,53 ppm, pada penambahan ekstrak kulit buah nenas $10 \%$ (P1) sebesar 17,02, sedangkan kadar protein terendah adalah pada kontrol ( $\mathrm{P} 0=$ tanpa perlakuan) yaitu sebesar 15,61 ppm. Hal ini menunjukkan bahwa kadar protein 
menunjukkan kecenderungan yang semakin meningkat seiring dengan penambahan volume ekstrak kulit buah nenas. Hal ini disebabkan oleh semakin meningkatnya kandungan enzim bromelin dalam bahan yang berfungsi sebagai biokatalisator yang akan mempercepat reaksi pemecahan protein menjadi asam amino.

Hasil uji Anava satu jalur terhadap kandungan protein tepung ampas kelapa dan analisis ragam, menunjukkan bahwa penambahan ekstrak kulit nenas dengan perlakuan PO, P1, P2, P3, dan P4, memberikan hasil protein terlarut yang tidak berpengaruh nyata terhadap peningkatan kadar protein pada tepung ampas kelapa. Konsentrasi ekstrak kulit buah nenas $20 \%$ yang diberikan merupakan konsentrasi yang optimum, sehingga memberikan hasil protein terlarut yang optimal pula. Penambahan ekstrak kulit nenas dengan konsentrasi $25 \%$ menunjukkan penurunan hasil protein terlarut yang menandakan aktifitas enzim bromelin menurun dalam menghidrolisis protein. Enzim bromelin adalah enzim yang bekerja secara optimal pada konsentrasi tertentu dan aktivitasnya secara umum akan menurunkan jika konsentrasi jenuh.

Hal ini disebabkan pada waktu pematangan buah terjadi pembentukan senyawa tertentu, dalam hal ini enzim mungkin ikut terpakai dalam senyawa tersebut sehingga sebagian struktur enzim akan rusak, akibatnya keaktifan berkurang. $\mathrm{pH}$, Aktivitas optimal dari enzim ini adalah pada derajat keasaman $(\mathrm{pH})$ sebesar 5-6, dimana enzim mempunyai aktifitas maksimal. $\mathrm{pH}$ terlalu tinggi atau rendah akan mengakibatkan terjadinya beberapa perubahan yaitu denaturasi protein dengan kecepatan katalisa menurun.

Suhu yang paling baik adalah $40{ }^{0} \mathrm{C}$, suhu diatas dan dibawah $40{ }^{0} \mathrm{C}$ mengakibatkan keaktifan enzim lebih rendah karena energi kinetik molekul substrat maupun enzim rendah sehingga kecepatan reaksi menjadi rendah. Konsentrasi enzim dan substrat: semakin tinggi konsentrasi enzim akan semakin mempercepat terjadinya reaksi. Konsentrasi enzim berbanding lurus dengan kecepatan reaksi.Jika sudah mencapai titik jenuhnya, maka konsentrasi substrat berbanding terbalik dengan kecepatan reaksi. Aktivator dan Inhibitor, aktivator adalah zat yang dapat mengaktifkan dan menggiatkan kerja enzim. Contohnya ion klorida, yang dapat mengaktifkan enzim amilase. Inhibitor adalah zat yang dapat menghambat kerja enzim (Greenberg, 1949).

\section{KESIMPULAN}

Berdasarkan hasil penelitian dan pembahasan dalam penelitian ini dapat diambil kesimpulan bahwa aktifitas enzim bromelin dari ekstrak kulit nenas (Ananas comosus Merr L.) terhadap peningkatan kadar asam amino tepung ampas kelapa (Cocos nucifera L.) dengan konsentrasi 10\%, 15\%, 20\%, 25\%, berpengaruh nyata terhadap peningkatan kadar protein tepung ampas kelapa. Karena penambahan ekstrak kulit nenas pada konsentrasi $25 \%$ memberikan kadar protein terlarut yang tertinggi dan pada konsentrasi $0 \%$ memberikan kadar protein terlarut yang terendah. 


\section{SARAN}

1. Perlu adanya penelitian lebih lanjut mengenai penambahan ekstrak kulit buah nenas dengan volume dan bahan yang berbeda.

2. Perlu dikembangkan lebih lanjut mengenai penelitian selain ekstrak kulit buah nenas sebagai peningkatan kadar protein tepung ampas kelapa, misalnya dengan seluruh bagian dari buah nanas atau hanya ampasnya saja.

3. Disarankan kepada peneliti selanjutnya untuk mencari variasi manfaat dari buah nenas.

4. Disarankan kepada masyarakat untuk menggunakan ampas kelapa dalam pembuatan tepung, karena di dalam tepung ampas kelapa terdapat protein yang masih tinggi

\section{DAFTAR PUSTAKA}

Abdurahman dan Mulyani, (2003) dalam jurnal Meddiati Fajri Putri, (2010). Jurnal Kompetensi Teknik Vol 1, No2. Diakses pada tanggal 09 Oktober 2014.

Cancel, 1979; Gonzales, (1990) cit Tangsuphon dan Coupland, (2005) dalam Jurnal Meddiati Fajri Putri. Tepung ampas kelapa pada umur panen 11-12 bulan sebagai bahan pangan sumber kesehatan. Jurnal Kompetensi Teknik Vol.1, No.2. hlm 46.

F. Laitupa. 2010. Pemanfaatan Eugenol Dari Minyak Cengkeh Untuk Mengatasi Ranciditas Pada Minyak Kelapa. Jurnal BAB_II.pdf. hlm 3.

Kamal Prihatman. 2000. Tentang Budidaya Pertanian. Nenas.pdf. akses pada tanggal 09 Oktober 2014. Hlm 1.

Meddiati Fajri Putri. 2010. Tepung Ampas Kelapa Pada Umur Panen 11-12 Bulan Sebagai Bahan Pangan. Jurnal kompetensi teknik. No 2. Vol 1:1-2.

Nina Yuliana Mulyawati. 2012. Pengaruh Ekstrak Kasar Kulit (Ananas Comosus L.) Terhadap Peningkatan Kadar Asam Amino Tepung Tape Singkong (Manihot utilissima L.). Skripsi. IAIN Ambon

Robinson. 1995. Kandungan Organik Tumbuhan Tinggi. Bandung: ITB.

Syarif dan Aris (1986) dalam Jurnal Meddiati Fajri Putri (2010). Jurnal kompetensi teknik. No 2. Vol 1. Diakses pada tanggal 09 Oktober 2014.

Suhardiyono, Pantastico, dalam Meddiati Fajri Putri. Tepung Ampas Kelapa Pada Umur Panen 11-12 Bulan Sebagai Bahan Pangan Sumber Kesehatan. Jurnal Kompetensi Teknik Vol.1, No.2, hlm 2. Mei 2010.

Warisno, (2003). Dalam F. Laitupa. 2010. Pemanfaatan Eugenol Dari Minyak Cengkeh Untuk Mengatasi Ranciditas Pada Minyak Kelapa. JUrnal BAB_II.pdf. Diakses Tanggal 09 Oktober 2014.

Waluyo, Iud. 2009. Mikrobiologi Umum. Malang: UMM Press. 
Zaenudin et al. (2000). dalam Meddiati Fajri Putri. Tepung Ampas Kelapa Pada Umur Panen 11-12 Bulan Sebagai Bahan Pangan Sumber Kesehatan. Jurnal Kompetensi Teknik Vol.1, No.2, hlm 2 . Mei 2010. 